\title{
The Components of an Innovation System: A Conceptual Innovation System Framework
}

\author{
Maria Eggink \\ Tshwane University of Technology, Nelspruit, South Africa
}

Correspondence should be addressed to: Maria Eggink; egginkme@tut.ac.za

Received date: 19 April 2013; Accepted date: 12 June 2013; Published date: 12 September 2013

Academic Editor: Mohamad Fauzan Noordin

Copyright (C) 2013. Maria Eggink. Distributed under Creative Commons CC-BY 3.0

\begin{abstract}
Innovation forms the basis of economic growth and development. The "innovation system" concept started receiving more attention in literature since the 1980s, but very few studies have attempted to explain the functioning of such a system. Therefore, the need arose to develop a model for an innovation system a gainst which specific innovation systems could be compared and evaluated. Different models for an innovation system, as described in literature, were evaluated against findings of empirical studies in literature. Subsequently, a conceptual, descriptive framework for an innovation system model was developed. The participants that play a role in the innovation system were found to include, primarily, the innovative firms that are at the centre of the innovation system due to their importance in the contribution to innovative activities. Innovative firms were found to be operating in a complex matrix of other participants or actors. It was further indicated that the strength of the linkages amongst participants has a positive effect on the innovative performance of the system and so is important for the transfer of finances, knowledge and technology. The conceptual model serves as a point of departure for the evaluation of innovation systems.
\end{abstract}

Keywords: conceptual model, innovation systems, innovation role players, linkages.

\section{Introduction}

Schumpeter's (1961) "Theory of economic development", first published in 1911, is the founding work on innovation theory. One of the points where the neo-Schumpeterian view has expanded on Schumpeter's theory since the 1980s is the concept that innovation takes place in a complex system. Carlsson (2007:857-858) pointed out that

Cite this Article as: Maria Eggink (2013), "The Components of an Innovation System: A Conceptual Innovation System Framework," Journal of Innovation and Business Best Practices, Vol. 2013 (2013), Article ID 768378, DOI: $10.5171 / 2013.768378$. 
Schumpeter neglected the multiple sources of information inputs and the importance of a national system of innovation due to his focus on the individual entrepreneur. There are three things, according to Carlsson, (2007:859), that result from the systems approach: first, it is "necessary to specify the components of the system"; second, "the relationship amongst various components must be analysed"; and finally, "the attributes or characteristics of the components need to be specified".

Many economists refer to the concept "innovation system", and more generally to "national innovation systems", but very few have attempted to explain the functioning of such systems. The conceptual models that were found in literature comprise of some of the elements or participants of innovation systems, but are not comprehensive. Therefore, the need arose to develop a model for an innovation system against which specific innovation systems could be compared and evaluated. Such an evaluation may contribute to the improvement of an innovation system that in turn could lead to an increase in innovative activity and eventually to economic development.

A descriptive framework was developed in the study that forms the basis for a conceptual model of an innovation system. The participants were identified and the roles of the different participants and the interaction and linkages amongst the different participants were thereafter determined.

\section{Methodology}

The model of an innovation system that is reported in this paper was conceptual in that it describes a system, the elements, objects or entities (in this case, the participants or actors) within the system, together with their relationships (or linkages). A diagram of the system is presented to facilitate visualisation of the system. Different models for an innovation system, as described in literature, were studied. The different participants of the innovation system were identified and their roles described. These participants and their roles were evaluated against findings of empirical studies in literature, as well as the determinants of innovation as established by Eggink (2012). Subsequently, a descriptive framework of a conceptual model for an innovation system was developed.

\section{The Systems of Innovation Concept}

An innovation system is defined as follows:

An innovation system consists of the participants or actors and their activities and interactions, as well as the socio-economic environment within which these actors or participants function that together determine the innovative performance of the system (Eggink, 2012:24).

Some of the interaction amongst these participants may be co-operative while others may be competitive. No single participant controls the workings of the system or the interaction amongst the participants, although there are participants, for example government, who exert a significant influence in or on such a system (Paterson, Adam \& Mullin, 2003:2). These actors or participants do not necessarily interact consciously with one another and the different participants may not necessarily have the same goal, either. Yet, the different participants each have an impact on one another (Nelson, 1996:276).

Each nation has some kind of NSI, no matter if it is working well or not, but an ideal innovation system does not exist (Balzat, 2006:29 and Fromhold-Eisebith, 2007:219; 220).

\section{The Innovation System Model}

The innovation system framework is presented in a diagram (Figure 1). This figure indicates that the innovative firms are the centre of the innovation system due to the importance of their contribution to innovative activities (Department of Innovation, Industry, Science and Research, 
2011; OECD, 1997:12; Edquist, 2005:192 and Nelson, 1996:278). Other participants that have been identified include suppliers and competitors, financial organisations and venture capitalists, customers, education and training bodies, government, science, technology and R\&D intermediaries, and international participants. The interaction and linkages with foreign participants or actors (multinational enterprises, foreign suppliers, competitors and customers) can also influence the performance of a national innovation system, depending on the global involvement of participants in the innovation system. Therefore, these international considerations are included in the model. The linkages can be formal or informal, intentional or incidental and may be formed amongst different kinds of participants. Both financial and knowledge flows take place through these linkages.

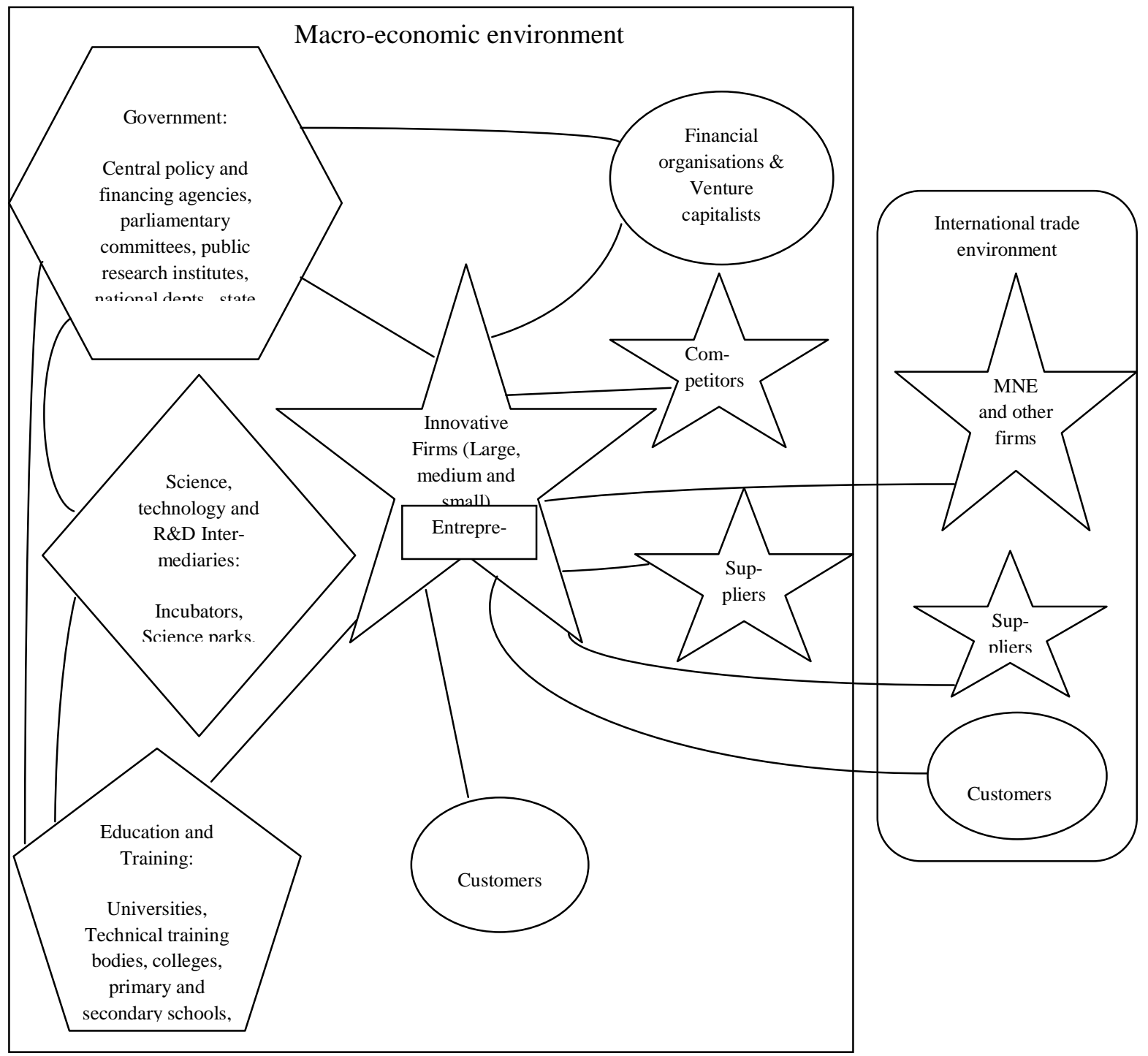

Fig. 1: Innovation system framework 
The different participants and their roles in the innovation system are as follow:

\section{Innovative Firms}

Schumpeter (1961) placed firms as the essential actors regarding innovation in his 1911 publication by describing the firms as the instruments used by entrepreneurs in the carrying out of innovations. Schumpeter's view, however, changed from the time of his first publications to the dates of his later publications, in the sense that he came to believe that innovation takes place in any size or age of firm and not only in new enterprises, as he initially stated. Although there is a positive relationship between size of the firm and innovation (Eggink, 2012), this does not imply that innovation takes place in large firms only.

The analysis of empirical studies on innovation by Becheikh, Landry and Amara (2006:657), revealed that networking by the firm with different actors was, in most studies, found to have a positive correlation with innovation, in some to have an insignificant correlation, but none of the studies recorded a negative correlation. Lee \& Park's (2006:1045) empirical study of Korean firms showed that collaborative R\&D with universities and downstream firms improved the chances of successful innovative activities.

There are many different kinds of linkages, depending on whether the linkages are formal or informal, intentional or incidental and depending on which participants are involved (for example, similar or different kinds of organisations, domestic or international participants).

(i) Formal linkages are consciously created and include both co-operative agreements and contractual specifications. Informal linkages emerge spontaneously and include examples such as trade fairs, personnel mobility, transfer of technology through machinery and equipment, scientific conferences and scientific publications.

(ii) Direct linkages are deliberately created. An example could be a situation where government provides financial support to firms in carrying out research and development (R\&D) activities. Indirect linkages emerge automatically, for example, if the technological knowledge of direct R\&D co-operation spills over unintentionally to a third party, then an indirect linkage to this third party has been established.

(iii) Horizontal linkages include linkages that take place amongst actors that belong to the same organisational category, for example, interaction between firms or interaction between research bodies. Vertical linkages are, again, linkages formed amongst actors of different organisational categories, for example, interaction amongst firms, universities, government and research bodies (Balzat, 2006:22-27; OECD, 1997:7).

The advantages that firms receive from collaboration include the pooling of technical resources, the achievement of economies of scale and the gaining of synergies from complementary human and technical assets (OECD, 1997:7).

\section{Suppliers and Competitors}

The other firms with which the innovating firms interact include suppliers and competitors. It should be kept in mind that each of these suppliers or competitors is an innovating firm in its own right, and is surrounded by its own suppliers, competitors and clients. The role that suppliers play in the innovation system includes the supplying of technologically improved inputs to the innovating firm and, therefore, the suppliers contribute to the innovative abilities of the firm. Competitors, according to Edquist (2005:196), play the role of motivating or supplying the incentives for the innovating firm to become more innovative. 
A very important role that the suppliers and competitors play in the innovation system is that of technology and knowledge transfer. Whether the linkages are formal or informal, the contacts amongst these firms whereby knowledge and expertise are transferred serve as both a source for, and stimulus to, innovation (OECD, 1997:7). Transactions take place amongst these participants and, through these transactions, the technology that is part and parcel of the product or service, together with the knowledge that lead to that technology, is transferred in that transaction (Edquist, 2005:196). According to Earl \& Gault (2006), the Community Innovation Survey (CIS), made by Eurostat in 2004, revealed that interactions with suppliers were the most important sources of information for innovation in European firms (apart from internal sources, that is), followed by fairs/exhibitions, competitors, and conferences/journals. The findings of Earl and Gault are confirmed by Bogliacino, Perani, Pianta and Supino (2009:12) in similar surveys for the EU and a group of developing countries.

\section{Financial Organisations and Venture Capitalists}

Financial organisations and venture capitalists also play an important role in the innovation system by providing the financial inputs needed by the innovating firm (Ahlbäck, 2005; Baskaran \& Muchie, 2010; and Holbrook, 1997). An efficient financial system is of strategic importance for an innovation system (Cooke, Uranga \& Etxebarria, 1997:481 and European Commission, 2003:149), and so differences in the national financial systems will influence the national and regional innovation systems.

Venture capital firms are particularly important for the success of new firms (Branscomb \& Auerswald, 2002:48). Malkiel (2007:325-330) offers evidence of the contribution of the venture capital industry's contribution to innovative activity. A particular advantage of venture capitalists is the mentoring and monitoring role of the venture capitalists that often contributes to the success of innovations. Financial organisations not only play the role of finance providers, but can also play an important role in knowledge transfer to firms. This link is usually stronger where there is more control involved in the agreement or contract.

\section{Customers}

Consumer's preferences should be considered in the innovation process and customers play a role in transferring knowledge to the firms. The studies done by Earl \& Gault, (2006:13), and Bogliacino et al., (2009:12), of different surveys both indicate that the customers play, in most cases, a stronger role even than do suppliers in knowledge transfer to firms. Bloch (2007:26) identified different aspects of how the customers may affect innovation. First, the knowledge of the needs of the users assists in generating new ideas; second, interaction with users leads to users assisting in seeking solutions for the development of new products; while thirdly, the responsiveness of customers to new products, that is, the propensity of customers to adopt new products, will also affect the requirement to innovate.

\section{Education, Training and Research Bodies}

Education and training bodies play very important roles in the development of human resources and some in R\&D too. Many studies such as those of Ahlbäck, 2005; Baskaran and Muchie, 2010; European Commission, 2003; Fromhold-Eisebith, 2007:217; Holbrook, 1997; Nelson, 1996:278; OECD \& Eurostat, 2005:37; Orford, Herrington and Wood, 2004:34; Paterson et al., 2003:9-10; and those of Rooks \& Oerlemans, 2005, all include education and training bodies in the innovation systems.

The role of the primary and secondary schools in the innovation system should be to provide quality education that can prepare people for tertiary education, as a sufficiently literate workforce and as potential entrepreneurs. Universities have a dual role 
to play in the innovation system: the education component and the research and development component. Universities play the role of promoting scientific knowledge and educating people, as well as initiating innovation, by generating knowledge and developing entrepreneurs (Greenhalgh \& Rogers, 2010:88; Miyata, 2003:715;736).

The OECD, as cited by Edquist (2005:192), claims that in most countries, universities are the most important public organisations performing R\&D. Universities play a leading role in basic research because firms do not benefit directly from it. Firms must first commercialise the basic research before they can benefit from it, and so they are often unwilling to carry the costs of basic research. However, the research role of Universities is not confined to basic research. Although firms contribute the most to applied research, universities are also involved in different forms of applied research. The examples that Miyata (2003:737) mentions include the generation of inventions, patents, licenses, informal communication with regional firms, and spin-off firms.

An interesting research publication is that of Chen \& Kenney, (2007), comparing two successful regional innovation systems in China, their process of development and the role of universities in the development process. The study concludes that the university research institutes have been significant contributors to growth in the Chinese economy. The study of Youtie and Shapira (2008) confirms the role of universities in the innovation system. They found, by comparing case studies of different universities, that the role of universities changed from performing conventional research and education functions to serving as innovation-promoting knowledge hubs.

\section{Governments}

The role of governments in the innovation system can be very expansive, particularly when all the different levels and divisions of governments are considered. Therefore, within the scope of this study, only a broad overview will be given of the role of governments in innovation systems.

The central role of government policy in the entrepreneurial economy should be enabling in nature and should seek to create an innovative environment (Department of Innovation, Industry, Science and Research, 2011). The role that governments play in creating an environment conducive to innovation includes the development of human resources of the country, as was discussed in the previous paragraph. $R \& D$ is partly fulfilled by private sector, but research by universities and certain institutions must also be included in the role that governments have to play. According to The World Bank (2010:140-141), business sectors finance the majority of R\&D, governments finance $30 \%$ of R\&D in OECD countries and universities finance $7 \%$. The $R \& D$ performance pattern is similar, but in developing countries governments plays the major role in financing and performance of R\&D. Paterson et al. (2003:4-8) classified performance of research, development and innovation as a shared role of government with private sector. According to Edquist (2005:193), the dependence of universities on governments varies in different countries.

The access to finances for innovative firms an important determinant of innovation - is partly the role of government (Paterson et al., 2003:4). Government can here play a vital role in improving access to finances, especially for new ventures that cannot easily locate other finances due to the risk involved. Further, the government must create an institutional framework that inspires confidence. Trust in government and political stability must be instilled. Laws and regulations should be supportive of innovative activities and should not hamper them. Policies should be put in place that support innovation; policy formulation and resource allocation should take place at national level; specialised advisory functions should be provided; regulatory policymaking should be in place; and national science, and technology and innovation 
international relations at the bi-lateral and multi-lateral levels should be sound (Paterson et al., 2003:4). The World Bank (2010:60) contends that there are a few "generic innovation policy functions": supporting innovators by appropriate incentives and mechanisms; removing obstacles to innovative initiatives; establishing responsive research structures; and by fostering a creative and receptive population through appropriate education systems.

\section{Science, Technology and R\&D Intermediaries}

The following are included in innovation intermediaries: industry and trade associations, economic development agencies, chambers of commerce, science, technology and business parks, business incubators, research consortia and networks, research institutes, technology transfer companies, industrial liaison offices, innovation centres, high quality industrial estates and standards organisations (Ahlbäck, 2005:12 and Phillimore \& Joseph, 2003:751). These innovation intermediaries often involve more than one of the participants in the innovation system. Innovation intermediaries play the role of a bridge linking knowledge directly or indirectly amongst actors, coordinating interests amongst actors and promoting the transformation of scientific and technological achievements (Siegel, Waldman, Atwater \& Albert, 2003:113). Dalziel (2010:3-4), however, cautions that these intermediaries are only classified as innovation intermediaries if their purpose is to enable innovation.

Urriago, Modrego, Barge-Gil and Paraskevopoulou (2010) show with an empirical study that science parks in Spain have a strong positive impact on the probability and amount of radical product innovation. These findings were further confirmed by the empirical study conducted by Squicciarini (2009:19) on Finnish firms, where Squicciarini found that locating inside the science parks positively relates to the innovative output performance of firms.

Depending on the form of intermediary, it can be deduced that the roles of intermediaries include transfer of knowledge; encouragement of small and/or new businesses and innovative activities; training of management and technical skills; cost benefits from sharing facilities; and access to advice on technical aspects, marketing, patenting, etc. Developed countries make extensive use of these intermediaries in their innovation systems, while developing countries have an even greater need for these intermediaries. Therefore, intermediaries should be promoted in developing countries in order to facilitate innovative activities in the innovation systems.

\section{International Participants}

However, it must not be thought that the innovation systems function in isolation. This is due to globalisation. In this section, the international participants are identified together with the roles that these participants play or the effects that they have on the innovation system. These international participants include, inter alia, firms outside the national boundaries, including foreign suppliers and competitors; customers of export products; and multinational enterprises (MNE).

Foreign suppliers, competitors and customers play the same role as do the domestic suppliers, competitors and customers. Together with the expanded markets, increased competition is, perhaps, an unwanted result of international trade (Eaton \& Kortum, 2006:2; 26; Schneider, 2005:529). On the other hand, this increased competition puts pressure on domestic firms to be more innovative (Schneider, 2005:530). As they interact, the foreign firms may also contribute to knowledge and technology transfer. The advantage for the domestic firm is that the foreign firms enhance their access to international innovative ideas. 
Multi-national enterprises (MNEs) are some of the participants that play a very important role in the innovation systems. According to the International Trade Institute of Southern Africa (2010: 47), MNEs form a huge component of international trade: MNEs are responsible for over $20 \%$ of world output and for more than $25 \%$ of intra-firm trade. The roles that the MNEs can play in the innovation system include international flows of knowledge through patenting, licensing, foreign direct investment (FDI), trade and scientific collaborations, and through R\&D, production and sales that take place in different countries (Bloch, 2007:25); financial resources and new factories; management experience, entrepreneurial abilities, technological skills; and technological knowledge about production processes through transferring modern machinery and equipment to capital-poor developing countries (Todaro \& Smith, 2009:720).

\section{Discussion}

It is important that the linkages among participants should be of such a nature as to enhance the appropriate financial flows. Financial flows among participants usually form part of direct and/or formal linkages. These financial flows may, for example, be between firms and financial institutions, firms and venture capitalists, firms part of multi-national enterprises, firms and government (supporting, for example, R\&D), government and universities, training and other research organisations, between government and any other organisation in the innovation system that is funded by government, for example (Ahlbäck, 2005; Baskaran \& Muchie, 2010; European Commission, 2003; Holbrook, 1997; and Rooks \& Oerlemans, 2005).

The knowledge flows are not as easily distinguishable as the financial flows because knowledge flows do not only take place through direct and formal linkages, but also through indirect and informal linkages.
The knowledge flows may be classified in three categories. The first category is that of open information sources, where access of knowledge is gained without payment for the knowledge itself. The second category of knowledge transfer is where the acquisition of technology and knowledge involves the purchase of external knowledge and technology without active co-operation with the source. The third category of knowledge transfer is through innovation co-operation which involves active participation in joint innovation projects with other organisations (OECD \& Eurostat, 2005:78-81).

All three categories of knowledge transfer contribute significantly to the innovation activities that take place in the innovation system. Rooks \& Oerlemans (2005:1216) regard knowledge as "the basic ingredient of innovation". Without knowledge that is transferred from education, training and research institutions through human resources to firms, the innovative capacity of firms would be seriously hampered. The flows of knowledge and technology among any of the participants in the innovation system, through any channel that has been discussed, will lead to an expansion of the total knowledge component in the innovation system as a whole. In turn, this will eventually lead to innovative activity and economic development. The flow of knowledge and technology across national borders is but one of the most important aspects to consider in any innovation system, due to the increasingly globalised economy and the increased competition that inevitably must accompany globalisation.

\section{Conclusion}

The purpose of this paper was to report on the development of a descriptive, conceptual framework of an innovation system model by presenting the participants and their roles in the innovation system.

The participants that play a role in the innovation system were found to include, primarily, the innovative firms that were at the centre of the innovation system due to 
their importance in the contribution to innovative activities, and this included large, medium and small enterprises. Innovative firms were found to be operating in a complex matrix of other participants or actors. Education and training bodies were found to be amongst the most important participants, supporting firms in the innovation system due to their contributions to the development of sufficiently qualified human resources and by their contribution to R\&D capacity - two of the most important determinants of innovation, as previously determined by Eggink (2012). The science, technology and R\&D intermediaries also contribute to the R\&D function and so played a strong role in the transfer of knowledge and technology and in the interaction and linkage amongst participants. The role of the government was seen as needing to be supportive. Financial institutions and venture capitalists were also found to be important participants to the innovative firms, due to the role that finances play in innovative activities. It was further indicated that international participants, although not inside the national boundaries of a national innovation system, influenced the innovation system because of globalisation.

It was further indicated that the strength of the linkages amongst participants had a positive effect on the innovative performance of the system and so was important for the transfer of finances, knowledge and technology. The transfer of knowledge from universities to firms or from MNEs to their national branches was one of the betterknown knowledge transfer linkages identified, but this did not imply that the knowledge transfer from, for example, suppliers to firms, or from customers to firms, was not important. The existence and strength of the participants alone did not determine the performance of the system. The strength and kinds of linkages amongst the participants played a role in the performance of the system as a whole.

Although an ideal innovation system does not exist due to the complexity of the system, the conceptual model framework described can serve as a point of departure for the evaluation of innovation systems. The identification of weaknesses or strengths in participants, their roles in innovation systems or the linkages between them, may lead to their improvement and subsequently to the improvement in the performance of such systems and the economic development of the community.

\section{References}

Ahlbäck, J. (2005). “The Finnish national innovation system", [Online], Helsinki: Helsinki University Press, Available from: http://www.helsinki.fi/euoffice/suomi/tiedo ttect/system.pdf [Accessed: 19/06/2006].

Australia Government: Department of Innovation, Industry, Science and Research. (2011). "Australian innovation system report 2011," Australia, Commonwealth of Australia, Available from:

http://www.innovation.gov.au/Inoovation/P olicy/AustralianInnovation

SystemReport/AISR2011/chapter-1-theperformance-of-the-australian-innovationsystem/what-is-an-innovation-system-andwhat-does-it-do/index.html [Accessed: 24/03/2013].

Balzat, M. (2006). “An economic analysis of innovation: Extending the concept of national innovation systems," Cheltenham, Edward Elgar.

Baskaran, A. \& Muchie, M. (2010). "Towards a unified conception of innovation systems". Pretoria, IERI, TUT, (IERI Working paper 2010 0002).

Becheikh, N., Landry, R. \& Amara, N. (2006). "Lessons from innovation empirical studies in the manufacturing sector: a systematic review of the literature from 1993-2003," Technovation, 26, 644-664.

Bloch, C. (2007). “Assessing recent developments in innovation measurement: 
the third edition of the Oslo Manual," Science and Public Policy, 34(1), Feb. 23-34.

Bogliacino, F., Perani, G., Pianta, M \& Supino, S. (2009). "Innovation in developing countries: The evidence from innovation surveys". (Paper read at the Italian National Research Programme (FIRB) Conference, September 7-8, Bocconi University, Milan), Unpublished.

Branscomb, LM. \& Auerswald, PE. (2002).

"Between invention and innovation: An analysis of funding for early-stage technology development," [Online], Gaithersburg, National Institute of Standards and Technology, (NIST GCR 02-841), Available from:

http://tsapps.nist.gov/ts_sbin/resources/gcr 02-841.pdf [Accessed: 17/03/2008].

Carlsson, B. (2007). "Innovation systems: a survey of the literature from a Schumpeterian perspective," In: Hanusch, H. \& Pyka, A. (Eds.), Elgar companion to NeoSchumpeterian economics, Cheltenham, Edward Elgar, 857-871.

Chen, K. \& Kenney, M. (2007).

"Universities/research institutes and regional innovation systems: the cases of Beijing and Shenzhen," World Development, 35(6), 1056-1074.

Cooke, P., Uranga, MG. \& Etxebarria, G. (1997). "Regional innovation systems: institutional and organizational dimensions," Research Policy, 26, 475-491.

Dalziel, M. (2010). “Why do innovation intermediaries exist?" (Paper read at the DRUID conference, June 16-18, Imperial College Business School, London) [Online], Available from:

http://www2.druid.dk/conferences/viewpa per.php?id=500976\&cf=43 [Accessed: 05/07/2011].

Department of Innovation, Industry, Science and Research see Australia Government: Department of Innovation, Industry, Science and Research
Earl, L. \& Gault, F. (2006). “An introduction to innovation and policy.”. In: Earl, L. \& Gault, F. (Eds.), National innovation, indicators and policy, Cheltenham, Edward Elgar, 3-7.

Eaton, J. \& Kortum, S. (2006). “Innovation, diffusion, and trade" [Online], Cambridge, National Bureau of Economic Research, (Working paper 12385), Available from: http://www.nber.org/papers/w12385.pdf [Accessed: 05/11/2010].

Edquist, C. (2005). "Systems of innovation: perspectives and challenges," In: Fagerberg, J., Mowery, DC. \& Nelson, RR. (Eds.), The Oxford handbook of innovation, New York, Oxford University Press, 181-208.

Eggink, ME. (2012). "The role of innovation in economic development". D.Com. thesis, Pretoria, University of South Africa.

European Commission. (2003). "Third report on Science and Technology Indicators 2003," Luxembourg, Office for Official Publications of the European Communities, (EUR 20025 EN).

Fromhold-Eisebith, M. (2007). "Bridging scales in innovation policies: How to link Regional, National and International Innovation Systems," European Planning Studies, 15(2), Feb. 217-233.

Greenhalgh, C. \& Rogers, M. (2010). "Innovation, intellectual property, and economic growth". Oxford, Princeton University Press.

Holbrook, JAD. (1997). "The use of national systems of innovation models to develop indicators of innovation and technological capacity". CPROST Report no. 97-06, Vancouver, Centre for Policy Research on Science and Technology.

International Trade Institute of Southern Africa. (2010). "International trade relations,” Rivonia, TRADSA.

Lee, J. \& Park, C. (2006). Research and development linkages in a national 
innovation system: factors affecting success and failure in Korea". Technovation, 26, 10451054.

Malkiel, BG. (2007). "Finance and innovation". In: Sheshiski, E., Strom, RJ. \& Baumol, WJ. (Eds.), Entrepreneurship, innovation, and the growth mechanism of the free-enterprise economies, Princeton, Princeton University Press, 324-336.

Miyata, Y. (2003). “An analysis of research and innovative activities of universities in the United States". In: Shavinina, LV. (ed.), The international handbook on innovation, Oxford, Elsevier, 715-738.

Nelson, RR. (1996). "The sources of economic growth". London, Harvard University Press.

OECD see Organisation for Economic Cooperation and Development.

OECD \& Eurostat see Organisation for Economic Co-operation and Development \& Statistical Office of the European Communities.

Organisation for Economic Co-operation and Development. (1997). "National innovation systems" [Online], France, OECD, Available from:

http://www.oecd.org/dataoecd/35/56/210 1733.pdf [Accessed: 10/06/2006].

Organisation for Economic Co-operation and Development \& Statistical Office of the European Communities. (2005). "Oslo Manual: Guidelines for collecting and interpreting innovation data: The measurement of scientific and technological activities," 3rd ed., Paris, OECD/European communities.

Orford, J., Herrington, M. \& Wood, E. (Eds.). (2004). "Global Entrepreneurship Monitor 2004: South African Report" [Online], Cape Town, University of Cape Town, Available from:

www.gsb.uct.ac.za/gsbwebb/userfiles/GEM_ 2004.pdf [Accessed: 07/11/2005].
Paterson, A., Adam, R. \& Mullin, J. (2003). "The relevance of the national system of innovation approach to mainstreaming science and technology and technology for development in NEPAD and the AU" [Online], Pretoria, The Department of Science and Technology, Available from:

http://www.nepad.org/2005/files/documen ts/125.pdf [Accessed: 19/06/2006].

Phillimore, J. \& Joseph, R. (2003). "Science Parks: A triumph of hype over experience?"

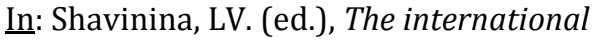
handbook on innovation, Oxford, Elsevier, 750-757.

Rooks, G. \& Oerlemans, L. (2005). "South Africa: A rising star?: Assessing the Xeffectiveness of South Africa's national system of innovation," European Planning Studies, 13(8), Dec. 1205-1222.

Schneider, PH. (2005). "International trade, economic growth and intellectual property rights: a panel data study of developed and developing countries," Journal of Development Economics, 78, 529-547.

Schumpeter, JA. (1961). “The theory of economic development: An inquiry into profits, capital, credit, interest and the business cycle," Translated by R. Opie, USA, Harvard University Press.

Siegel, DS., Waldman, DA., Atwater, LE. \& Albert, NL. (2003). “Commercial knowledge transfers from universities to firms: improving the effectiveness of universityindustry collaboration" [Online], Journal of High Technology Management Research, 14, 111-133, Available from:

http://www.sciencedirect.com/science/artic le/pii/S1047831003000075 [Accessed: 15/11/2011].

Squicciarini, M. (2009). "Science parks, knowledge spillovers, and firms' innovative performance: Evidence from Finland," Economics E-Journal [Online], Jul. 1-28, Available from: http://www.economicsejournal.org/economics/discussionpapers/2 009-32 [Accessed: 05/07/2011]. 
Todaro, MP. \& Smith, SC. (2009). "Economic development," 10th ed., Harlow, Addison Wesley.

Urriago, URV., Modrego, A., Barge-Gil A. \& Paraskevopoulou, E. (2010). "The impact of science and technology parks on firms' radical product innovation: Empirical evidence from Spain," (Paper read at the DRUID conference, June 16-18, Imperial College Business School, London [Online], Available from: http://www2.druid.dk/conferences/viewpa per.php?id=500976\&cf $=43$ [Accessed: 05/07/2011].

The World Bank. (2010). "Innovation policy: a guide for developing countries," Washington, The World Bank.

Youtie, J. \& Shapira, P. (2008). “Building an innovation hub: a case study of the transformation of university roles in regional technological and economic development," Research Policy, 37, 1188-1204. 